\title{
Therapeutic regimens for vitamin $D$ deficiency in postmenopausal women: a systematic review
}

\author{
Yasin Tayem ${ }^{1}$, Raed Alotaibi², Reham Hozayen², Adla Hassan ${ }^{3}$ \\ ${ }^{1}$ Department of Pharmacology and Therapeutics, College of Medicine and Medical Sciences, Arabian Gulf University, Manama, Bahrain \\ ${ }^{2}$ Salmaniya Medical Complex, Manama, Bahrain \\ ${ }^{3}$ Department of Medicine, College of Medicine and Medical Sciences, Arabian Gulf University, Manama, Bahrain
}

\begin{abstract}
Introduction: We reviewed the most effective vitamin D3 regimen for vitamin D deficiency in postmenopausal women.

Material and methods: We searched for studies and clinical trials conducted on healthy postmenopausal women published on PubMed from 2000 to 2018 using the term "Vitamin D deficiency" combined with the following terms: "dose", "supplement", "supplementation", "cholecalciferol" or "cholecalciferol dose". We identified 1376 articles which matched the search criteria. Based on reviewing the title and abstract, 17 articles were eligible for a full-text review. Of those, 12 manuscripts were ultimately included.

Results: A majority of the studies (75\%) reported using daily maintenance doses which were predominantly administered orally (83.3\%). Two studies reported favorable results following therapy with a single oral dose of 300,000 IU. After one month, however, 25 -hydroxy vitamin D [25(OH)D] was satisfactory; both studies failed to maintain adequate responses after 60 and 90 days. One study found that loading oral doses of 50,000 IU/ day for 2 weeks followed by the same doses every 2 weeks for one year were effective. Five studies employed oral doses of $800 \mathrm{IU} /$ day but none of them reported that this dose was adequate. Three studies used doses of $1000 \mathrm{IU} /$ day but only two of them reported positive results. Three trials examined oral doses of $2000 \mathrm{IU} /$ day and another 3 studies tested oral doses of 4000-4800 IU/day. All of them reported acceptable responses that lasted with continued treatment.

Conclusions: Oral maintenance doses of 2000-4800 IU/day satisfactorily corrected vitamin D deficiency and maintained $25(\mathrm{OH}) \mathrm{D}$ levels in postmenopausal women with continuous therapy.
\end{abstract}

Key words: vitamin D3, postmenopausal women, vitamin D deficiency.

\section{Introduction}

Vitamin $D$ is an essential fat-soluble vitamin that is obtained from dietary sources and unrestricted exposure to sunlight. The latter stimulates cutaneous synthesis of this essential vitamin from solar radiation. Measurement of circulating 25-hydroxyvitamin D [25(OH)D] is considered to be the gold standard test for vitamin $D$ status in the body. Under most clinical settings, vitamin $D$ insufficiency and deficiency are both diagnosed if serum $25(\mathrm{OH}) \mathrm{D}$ levels are found to be less than $30 \mathrm{ng} / \mathrm{ml}$ and $20 \mathrm{ng} / \mathrm{ml}$, respectively. Vitamin $D$ inadequacy adversely affects bone health due to secondary hyperparathyroidism, which excessively stimulates bone remodeling and causes fragility. As a result, vitamin $D$ deficiency causes serious bone complications such as rickets, osteomalacia, osteoporosis, and fractures [1]. In addition to the adverse outcomes of vitamin $\mathrm{D}$ inadequacy on bones, several other systemic diseases have been linked to the deficiency of this vitamin, including autoimmune diseases, cancer, and cardiovascular diseases [2].

Although vitamin $D$ deficiency is common among all age groups, it is especially prevalent among women after menopause, possibly due to poor exposure to sunlight and insufficient intake of vitamin $D$ from diet [3]. Postmenopausal women who are vitamin D deficient are prone to develop serious complications such as osteoporosis and consequent catastrophic fractures of the neck of the femur and vertebral column [4]. The prevalence of vitamin D deficiency in postmenopausal women varies in different countries. Indeed, in the European Union, $32.1 \%$ of women after menopause were estimated to have $25(\mathrm{OH}) \mathrm{D}$ less than $20 \mathrm{ng} / \mathrm{ml}$ 
[5] whereas in India, China and the United States, the prevalence of vitamin D inadequacy was reported to be $53.3 \%, 72.1 \%$, and $53 \%$, respectively [6-8].

A significant debate exists regarding the most effective therapeutic regimen for correcting vitamin $D$ deficiency in postmenopausal women. In this context, several clinical trials have been conducted to investigate the most appropriate dose, route of administration and duration of therapy with varying outcomes. In this systematic literature review, we aimed to draw conclusions on the most appropriate treatment protocol for vitamin $D$ deficiency in this group of women.

\section{Material and methods}

We searched PubMed over the period 2000 to 2018 using the following search terms: "Vitamin D deficiency dose", "Vitamin D deficiency supplement", "Vitamin D deficiency supplementation", "Vitamin D deficiency cholecalciferol", and "Vitamin D deficiency cholecalciferol dose". Studies were included if they were original articles, clinical or randomized clinical trials, published in English, conducted on vitamin D deficient but healthy postmenopausal women, using vitamin D3 (cholecalciferol). Manuscripts were excluded if they were review articles, cross-sectional studies, or conducted on animals or in vitro. Studies were also not included if the full article was not available or if vitamin D analogs, other than vitamin D3, were used. Articles were also eliminated if they were conducted on mixed populations such as men and women or involved mixed age groups, if the route of administration and duration of therapy were not clearly stated and if baseline and post-treatment 25(OH)D were not reported. Eligible manuscripts were initially reviewed by reading the title and abstract, but when the reviewers were not able to make a decision, the full article was reviewed. Eligible articles were identified by two independent reviewers. However, in the case of disagreements two additional reviewers were consulted. The outcome of interest in this review was the change in $25(\mathrm{OH}) \mathrm{D}$ levels after treatment with vitamin D3. Regimens reported in the included studies were considered effective if the post-treatment 25(OH)D level exceeded the cutoff point of $30 \mathrm{ng} / \mathrm{ml}$.

\section{Results}

\section{Search results}

We identified 1376 articles which matched the search criteria (Fig. 1). Based on reviewing title and abstract, 1359 articles were excluded as per the exclusion criteria. The 17 articles which were eligible for full-text review were read in full by the investigators. Out of those, 5 manuscripts were further excluded as follows: One article was in Spanish, one article did not specify the baseline $25(\mathrm{OH}) \mathrm{D}$, two articles were conducted on nonvitamin $\mathrm{D}$ deficient women, and one article was based on data obtained from another included article. The remaining 12 manuscripts were finally included (Table 1).

\section{Review results}

Vitamin D3 was administered orally in the majority of the included manuscripts. Indeed, only one study tested intramuscular vitamin D3, while the remaining 11 articles reported using the oral route. Regarding the tested doses and duration of treatment, most studies investigated low daily doses of vitamin D3 which ranged from 200 to 4800 IU/day for 2-12 months

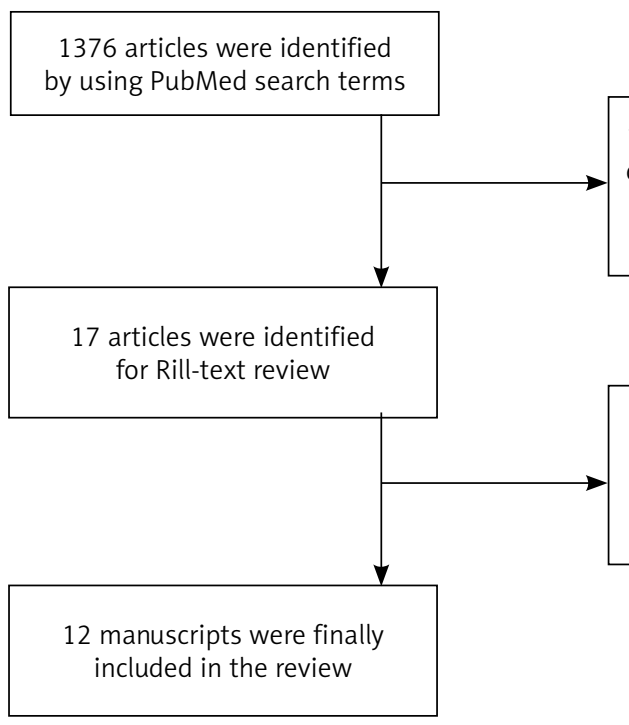

1359 articles were excluded based on the exclusion criteria (for instance reports on non-human studies, non-English, pre- or post-treatment 25(OH)D were not specified etc.)

Fig. 1. Flow diagram for the articles which were identified for the review 
Table 1. Summary of included studies.

\begin{tabular}{|c|c|c|c|c|}
\hline $\begin{array}{l}\text { Author, } \\
\text { year }\end{array}$ & $\begin{array}{c}\text { Postmenopausal } \\
\text { women's characteristics/ } \\
\text { Randomization/Study quality } \\
\text { testing }\end{array}$ & $\begin{array}{c}\text { Study design/ } \\
\text { Vitamin D3 regimen }\end{array}$ & $\begin{array}{l}\text { Mean baseline and } \\
\text { post-treatment } \\
25(\mathrm{OH}) \mathrm{D}, \mathrm{ng} / \mathrm{ml}\end{array}$ & Conclusions \\
\hline \multirow[t]{2}{*}{$\begin{array}{l}\text { Hansen, } \\
2015\end{array}$} & \multirow[t]{2}{*}{$\begin{array}{c}\text { N: } 230 \\
\text { Age: } 61 \pm 6 \text { years } \\
\text { Block randomization was } \\
\text { performed } \\
\text { Intent to treat was performed }\end{array}$} & $\begin{array}{l}\text { Randomized clinical trial } \\
\text { Loading dose of oral } \\
50,000 \text { IU/day for } \\
15 \text { days followed by } \\
\text { maintenance dose of oral } \\
50,000 \text { IU every } 2 \text { weeks } \\
\text { for } 11.5 \text { months }\end{array}$ & $\begin{array}{l}\text { Baseline: } 21 \pm 3 \\
\text { Post-treatment: } \\
30 \text { days: } 80 \\
60 \text { days: } 59 \\
120 \text { days: } 46 \\
240 \text { days: } 45 \\
365 \text { days: } 42\end{array}$ & $\begin{array}{c}\text { Oral loading dose of } \\
50,000 \mathrm{IU} / \text { day for } 2 \text { weeks followed } \\
\text { by } 50,000 \mathrm{IU} / 2 \text { weeks for a year was } \\
\text { effective for raising } 25(\mathrm{OH}) \mathrm{D} \text { level } \\
\text { above normal a and was maintained } \\
\text { up to } 1 \text { year }\end{array}$ \\
\hline & & $\begin{array}{l}\text { Randomized clinical trial } \\
\text { Maintenance dose of oral } \\
800 \text { IU/day for } 12 \text { months }\end{array}$ & $\begin{array}{l}\text { Baseline: } 21 \pm 3 \\
\text { Post-treatment: } \\
30 \text { days: } 26 \\
60 \text { days: } 27 \\
120 \text { days: } 29 \\
240 \text { days: } 28 \\
365 \text { days: } 27\end{array}$ & $\begin{array}{l}\text { Maintenance oral dose of } \\
800 \text { IU/day was not sufficient to raise } \\
\text { serum } 25(\mathrm{OH}) \mathrm{D} \text { level to normal, } \\
p<0.001^{\mathrm{b}}\end{array}$ \\
\hline \multirow[t]{2}{*}{$\begin{array}{l}\text { Romagnoli, } \\
2008\end{array}$} & \multirow{2}{*}{$\begin{array}{c}\mathrm{N}: 32 \\
\text { Age range: } 66-97 \text { years } \\
\text { No information on } \\
\text { randomization was stated } \\
\text { No study quality testing was } \\
\text { reported }\end{array}$} & $\begin{array}{l}\text { Prospective randomized } \\
\text { intervention study } \\
\text { Loading oral dose of } \\
300,000 \mathrm{IU}\end{array}$ & $\begin{array}{c}\text { Baseline: } 13.3 \pm 9.9 \\
\text { Post-treatment: } \\
30 \text { days: } 47.8 \pm 7.3 \\
60 \text { days: } 28.06 \pm 8.33\end{array}$ & \multirow{2}{*}{$\begin{array}{c}\text { A single oral dose of } 300,000 \mathrm{IU} \\
\text { had a faster onset and was more } \\
\text { effective than equal intramuscular } \\
\text { dose in elevating } 25(\mathrm{OH}) \mathrm{D} \text { to } \\
\text { normal levels but after } 60 \text { days, } \\
\text { neither doses were effective in } \\
\text { keeping } 25(\mathrm{OH}) \mathrm{D} \text { level cbove } \\
\text { normal, }\left(p<0.001^{c}\right)\end{array}$} \\
\hline & & $\begin{array}{l}\text { Prospective randomized } \\
\text { intervention study } \\
\text { Loading intramuscular } \\
\text { dose of } 300,000 \mathrm{IU}\end{array}$ & $\begin{array}{c}\text { Baseline: } 8.3 \pm 3.6 \\
\text { Post-treatment: } \\
\text { 30 days: } 15.91 \pm 11.3 \\
60 \text { days: } 26.16 \pm 12.1\end{array}$ & \\
\hline $\begin{array}{l}\text { Aloia, } \\
2014\end{array}$ & $\begin{array}{c}N: 76 \\
\text { Age: } 58 \pm 4.9 \\
\text { Computer randomization was } \\
\text { performed } \\
\text { No study quality testing was } \\
\text { reported }\end{array}$ & $\begin{array}{l}\text { Randomized clinical trial } \\
\text { Maintenance oral doses } \\
\text { of } 800,2000 \text {, or } \\
4000 \text { IU/day for } 2 \text { months }\end{array}$ & $\begin{array}{l}\text { Baseline: } 25.2 \pm 5.6 \\
\text { Post-treatment: } \\
\text { Mean at } 800: 26 \\
\text { Mean at 2000: } 32 \\
\text { Mean at 4000: } 40\end{array}$ & $\begin{array}{l}\text { Maintenance oral dose of } 800 \mathrm{IU} / \text { day } \\
\text { was not effective. Maintenance oral } \\
\text { dose of } 2000 \mathrm{IU} / \text { day successfully } \\
\text { raised } 25(\mathrm{OH}) \mathrm{D} \text { to normal. } \\
\text { Maintenance oral dose of } 4000 \mathrm{IU} / \text { day } \\
\text { produced the highest response } \\
\qquad\left(p=0.002^{\mathrm{b}}\right)\end{array}$ \\
\hline $\begin{array}{l}\text { Ceglia, } \\
2016\end{array}$ & $\begin{array}{c}\text { N: } 21 \\
\text { Age: } 78 \pm 5 \\
\text { No information on } \\
\text { randomization was stated } \\
\text { No study quality testing was } \\
\text { reported }\end{array}$ & $\begin{array}{l}\text { Randomized clinical trial } \\
\text { Maintenance oral doses } \\
\text { of } 4000 \text { IU/day for } \\
4 \text { months }\end{array}$ & $\begin{array}{l}\text { Baseline: } 17.6 \pm 4 \\
\text { Post-treatment: } \\
32 \pm 4.8\end{array}$ & $\begin{array}{l}\text { Maintenance oral dose of } \\
4000 \text { IU/day was effective for } \\
\text { raising serum } 25(\mathrm{OH}) \mathrm{D} \text { above } \\
\text { normal }\left(p<0.01^{\mathrm{d}}\right)\end{array}$ \\
\hline $\begin{array}{l}\text { Golombick, } \\
2008\end{array}$ & $\begin{array}{c}\text { N: } 23 \\
\text { Age: } 61.2 \pm 3.2 \\
\text { No study quality testing was } \\
\text { reported }\end{array}$ & $\begin{array}{l}\text { Prospective open-label } \\
\text { study } \\
\text { Maintenance oral dose of } \\
1000 \text { IU/day for } 1 \text { month } \\
\text { then } 500 \text { IU/day for } \\
2 \text { months } \\
\end{array}$ & $\begin{array}{l}\text { Baseline: } 14.4 \pm 0.4 \\
\text { Post-treatment: } \\
36 \pm 2.4\end{array}$ & $\begin{array}{l}\text { Loading dose of oral } \\
1000 / \text { day for one month followed } \\
\text { by maintenance oral dose of } \\
500 \text { IU/day for one month raised } \\
\text { serum } 25(\mathrm{OH}) \mathrm{D} \text { to normal in } 86 \% \\
\text { of women }\left(p=0.0001^{\mathrm{d}}\right)\end{array}$ \\
\hline $\begin{array}{l}\text { Cangussu, } \\
2015\end{array}$ & $\begin{array}{c}N: 160 \\
\text { Age: } 58.8 \pm 6.6 \\
\text { Computer randomization was } \\
\text { performed } \\
\text { Intent to treat was performed }\end{array}$ & $\begin{array}{c}\text { Randomized clinical trial } \\
\text { Oral } 1000 \text { IU/day for } \\
9 \text { months }\end{array}$ & $\begin{array}{l}\text { Baseline: } 15 \pm 7.5 \\
\text { Post-treatment: } \\
27.5 \pm 10.4\end{array}$ & $\begin{array}{c}\text { Maintenance oral dose of } \\
1000 \text { IU/day for } 9 \text { months was not } \\
\text { sufficient to raise serum } 25(\mathrm{OH}) \mathrm{D} \\
\text { to normal }\left(p<0.001^{\mathrm{d}}\right)\end{array}$ \\
\hline \multirow[t]{2}{*}{$\begin{array}{l}\text { Thomas, } \\
2010\end{array}$} & \multirow{2}{*}{$\begin{array}{c}\text { N: } 22 \\
\text { Mean age: } 66 \\
\text { Computer randomization was } \\
\text { performed } \\
\text { No study quality testing was } \\
\text { reported }\end{array}$} & $\begin{array}{c}\text { Randomized clinical trial } \\
\text { Oral } 1000 \text { IU/day for } \\
7 \text { weeks }\end{array}$ & $\begin{array}{l}\text { Baseline: } 19.6 \\
\text { Post-treatment: } \\
30.8 \pm 7.2\end{array}$ & \multirow{2}{*}{$\begin{array}{c}\text { Maintenance oral dose of } \\
1000 \text { IU/day for } 7-8 \text { weeks was } \\
\text { sufficient to raise serum } 25(O H) D \\
\text { to normal }\left(p<0.001^{d}\right)\end{array}$} \\
\hline & & $\begin{array}{c}\text { Randomized clinical trial } \\
\text { Oral } 1000 \text { IU/day for } \\
8 \text { weeks }\end{array}$ & $\begin{array}{l}\text { Baseline: } 19.6 \\
\text { Post-treatment: } \\
36 \pm 10\end{array}$ & \\
\hline $\begin{array}{l}\text { Gallagher, } \\
2012\end{array}$ & $\begin{array}{c}N: 163 \\
\text { Age: } 67 \pm 7.3 \\
\text { Computer randomization was } \\
\text { performed } \\
\text { No study quality testing was } \\
\text { reported }\end{array}$ & $\begin{array}{l}\text { Randomized clinical trial } \\
\text { Oral } 4800 \text { IU/day } \\
\text { for } 12 \text { months }\end{array}$ & $\begin{array}{c}\text { Baseline: } 15.3 \pm 3.7 \\
\text { Post-treatment: } \\
46.5\end{array}$ & $\begin{array}{c}\text { Maintenance oral dose of } \\
4800 \text { IU/day for } 12 \text { months was } \\
\text { effective to raise serum } 25(\mathrm{OH}) \mathrm{D} \\
\text { above normal }\end{array}$ \\
\hline
\end{tabular}




\begin{tabular}{|c|c|c|c|c|}
\hline $\begin{array}{l}\text { Author, } \\
\text { year }\end{array}$ & $\begin{array}{c}\text { Postmenopausal } \\
\text { women's characteristics/ } \\
\text { Randomization/Study quality } \\
\text { testing } \\
\end{array}$ & $\begin{array}{l}\text { Study design/ } \\
\text { Vitamin D3 regimen }\end{array}$ & $\begin{array}{l}\text { Mean baseline and } \\
\text { post-treatment } \\
25(\mathrm{OH}) \mathrm{D}, \mathrm{ng} / \mathrm{ml}\end{array}$ & Conclusions \\
\hline $\begin{array}{l}\text { Mason, } \\
2016\end{array}$ & $\begin{array}{c}\text { N: } 218 \\
\text { Age: } 59.6 \pm 5.9 \\
\text { Block randomization was } \\
\text { performed } \\
\text { Intent to treat was performed }\end{array}$ & $\begin{array}{l}\text { Randomized clinical trial } \\
\text { Oral } 2000 \text { IU/ day } \\
\text { for } 12 \text { months }\end{array}$ & $\begin{array}{l}\text { Baseline: } 21.4 \pm 5.1 \\
\text { Post-treatment: } 35\end{array}$ & $\begin{array}{c}\text { Maintenance oral dose of } \\
2000 \mathrm{IU} / \text { day for } 12 \text { months was } \\
\text { sufficient to raise serum } 25(\mathrm{OH}) \mathrm{D} \\
\text { above normal }\left(p=0.02^{\mathrm{d}}\right)\end{array}$ \\
\hline $\begin{array}{l}\text { Talwar, } \\
2007\end{array}$ & $\begin{array}{c}\text { N: } 208 \\
\text { Age: } 59.9 \pm 6.2 \\
\text { Computer randomization was } \\
\text { performed } \\
\text { Intent to treat was performed }\end{array}$ & $\begin{array}{l}\text { Randomized clinical trial } \\
\text { Oral } 800 \text { IU/day } \\
\text { for } 24 \text { months followed } \\
\text { by oral } 2000 \mathrm{IU} / \text { day } \\
\text { for another } 12 \text { months }\end{array}$ & $\begin{array}{l}\text { Baseline: } 18.8 \pm 8.4 \\
\text { Post-treatment: } \\
3 \text { months: } 28.4 \pm 8.8 \\
24 \text { months: } 26.4 \pm 8.8 \\
27 \text { months: } \\
34.8 \pm 10.8 \\
36 \text { months: } \\
29.6 \pm 10.8\end{array}$ & $\begin{array}{l}\text { Maintenance oral dose of } \\
800 \mathrm{IU} / \text { day for } 24 \text { months was not } \\
\text { sufficient to raise serum } 25(\mathrm{OH}) \mathrm{D} \\
\text { to normal. Maintenance oral dose } \\
\text { of } 2000 \mathrm{IU} / \text { day for } 12 \text { months was } \\
\text { effective to raise serum } 25(\mathrm{OH}) \mathrm{D} \\
\text { above normal in } 50 \% \text { of women } \\
\qquad\left(p<0.0001^{\mathrm{d}}\right)\end{array}$ \\
\hline $\begin{array}{l}\text { Viljakainen, } \\
2006\end{array}$ & $\begin{array}{c}\text { N: } 49 \\
\text { Age: } 65-85 \\
\text { No information on } \\
\text { randomization was stated } \\
\text { No study quality testing was } \\
\text { reported }\end{array}$ & $\begin{array}{l}\text { Randomized clinical trial } \\
\text { Oral } 200,400 \text {, or } \\
800 \text { IU/day for } 3 \text { months }\end{array}$ & $\begin{array}{l}\text { Baseline: } 18.8 \pm 6 \\
\text { Post-treatment: } \\
200 \text { IU/day: } \\
23.2 \pm 3.6 \\
400 \text { IU/day: } 24 \pm 3.6 \\
\text { At } 800: 28.4 \pm 3.6\end{array}$ & $\begin{array}{c}\text { Maintenance oral dose of } \\
800 \mathrm{IU} / \text { day for } 3 \text { months failed } \\
\text { to raise serum } 25(\mathrm{OH}) \mathrm{D} \text { above } \\
\text { normal }\end{array}$ \\
\hline \multirow[t]{2}{*}{$\begin{array}{l}\text { Apaydin, } \\
2018\end{array}$} & \multirow{2}{*}{$\begin{array}{c}N: 60 \\
\text { Age range: } 50-68 \\
\text { No information on } \\
\text { randomization was stated } \\
\text { No study quality testing was } \\
\text { reported }\end{array}$} & $\begin{array}{c}\text { Randomized clinical trial } \\
\text { A single oral dose of } \\
300,000 \mathrm{IU}\end{array}$ & $\begin{array}{c}\text { Baseline: } 9.7 \pm 4.4 \\
\text { Post-treatment: } \\
1 \text { month: } 35.9 \pm 9.6 \\
3 \text { months: } 23.1 \pm 4.7 \\
\end{array}$ & \multirow{2}{*}{$\begin{array}{l}\text { Maintenance oral dose of } 800 \mathrm{IU} / \text { day } \\
\text { for } 3 \text { months was not sufficient to raise } \\
\text { serum } 25(\mathrm{OH}) \mathrm{D} \text { above normal ( } 3.2 \% \\
\text { of treated women had repletion). } \\
\text { A single oral dose of } 300,000 \mathrm{IU} \text { was } \\
\text { more effective }(63.3 \% \text { of women } \\
\left.\text { were repleted, } p=0.049^{\circ}\right) \text { but did not } \\
\text { maintain } 25(\mathrm{OH}) \mathrm{D} \text { level above normal } \\
\text { after } 3 \text { months of follow-up }\end{array}$} \\
\hline & & $\begin{array}{l}\text { Randomized clinical trial } \\
\text { Oral } 800 \text { IU/day } \\
\text { for } 3 \text { months }\end{array}$ & $\begin{array}{l}\text { Baseline: } 10.2 \pm 4.4 \\
\text { Post-treatment: } \\
1 \text { month: } 16.9 \pm 5.8 \\
3 \text { months: } 19.8 \pm 7.2\end{array}$ & \\
\hline
\end{tabular}

IU - international unit, $25(\mathrm{OH}) \mathrm{D}-25$-hydroxyvitamin $\mathrm{D}$, ${ }^{\mathrm{N}}$ Normal $25(\mathrm{OH}) \mathrm{D}$ level is $30 \mathrm{ng} / \mathrm{ml}$, bamong all groups, cbetween the two treatment groups, ${ }^{\mathrm{d}}$ pre- and post-treatment

(9 studies). One study reported administering a single high dose of 300,000 IU while another 2 studies compared high doses which ranged from 50,000 to 300,000 IU with low daily doses.

Regarding the studies which tested high doses of vitamin D3, Romagnoli et al. described the outcomes of administering a single high dose of 300,000 IU orally or intramuscularly [9]. The oral dose successfully corrected $25(\mathrm{OH}) \mathrm{D}$ values. However, follow-up of vitamin D status demonstrated failure of this regimen to maintain 25(OH)D levels beyond sufficiency after 60 days. In comparison, an equal dose of vitamin D3 administered intramuscularly was not effective to correct vitamin D deficiency either after 30 days or after 60 days. Apaydin et al. reported the efficacy of administering an oral dose of 300,000 IU but adequate levels of $25(\mathrm{OH}) \mathrm{D}$ were not maintained after 3 months of follow-up [10]. Hanssen et al., on the other hand, reported treatment with loading doses of 50,000 IU/day daily for 2 weeks followed by the same dose every 2 weeks for one year [11]. Monitoring of the mean 25(OH)D levels showed that levels of $80 \mathrm{ng} / \mathrm{ml}$ after 4 weeks and mean levels above $30 \mathrm{ng} / \mathrm{ml}$ were maintained for one year.
For trials which investigated low daily doses of vitamin D3, five studies reported administering oral doses of $800 \mathrm{IU} /$ day, but none of them revealed that this dose was effective in raising mean $25(\mathrm{OH}) \mathrm{D}$ above $30 \mathrm{ng} / \mathrm{ml}$ [10-14]. Three studies used an oral dose of 1000 IU/day, though the results were conflicting. Cangussu and his colleagues found that, after 9 months of continuous therapy with this dose, the $25(\mathrm{OH}) \mathrm{D}$ response was suboptimal [15]. However, Colombick et al. [16] and Thomas et al. [17] revealed mean values of more than $30 \mathrm{ng} / \mathrm{ml}$ after around 2 months of treatment with this dose. All the remaining studies reported regimens which examined doses beyond 2000 IU/day and all of them reported positive results. Indeed, Aloia et al. [12], Talwar et al. [13] and Mason et al. [18] tested administering an oral dose of $2000 \mathrm{IU} /$ day for 2-12 months, and all of them reported an increase in mean $25(\mathrm{OH}) \mathrm{D}$ that was consistently above $30 \mathrm{ng} / \mathrm{ml}$. Aloia et al. [12] and Ceglia et al. [19] reported using an oral dose of 4000 IU/day for 2 and 4 months, respectively. Both doses invariably elevated mean 25(OH)D above the sufficiency level. Lastly, Viljakainen and coworkers reported using an oral dose of 4800 IU/day for 1 year [14]. The investigators revealed 
that this dose resulted in an increase in the mean vitamin $\mathrm{D}$ levels to $46.5 \mathrm{ng} / \mathrm{ml}$ at the end of the treatment period.

\section{Discussion}

By conducting an extensive literature review, this study aimed to draw conclusions on the most effective regimen for correcting vitamin $D$ deficiency in women after menopause using vitamin D3. For this purpose, we reviewed clinical trials conducted on vitamin $D$ deficient, healthy postmenopausal women over the period 2000 to 2018. The reviewed articles described different regimens for correcting vitamin $D$ deficiency which used variable doses, routes of administration and duration of therapy. Overall, our findings reported that daily maintenance doses ranging from 2000 to 4800 IU/day were the most effective and most commonly used in the included studies. Those regimens not only increased $25(\mathrm{OH}) \mathrm{D}$ to adequate levels but they consistently maintained it with continued therapy.

Our findings revealed that oral vitamin $D$ was the most effective and most commonly used route of administration, compared to the intramuscular one which was employed occasionally and reported to be subtherapeutic in some of the studies. Indeed, Romagnoli et al. found that intramuscular administration of a single high dose of 300,000 IU of vitamin D3 failed to correct vitamin $D$ deficiency compared to an equal dose that was administered orally [9]. In line with these data, Zabihiyeganeh et al., conducted a randomized clinical trial in which participants were administered 300,000 IU either orally or intramuscularly in six divided doses over three months. At the end of the treatment period, measurement of $25(\mathrm{OH}) \mathrm{D}$ levels revealed that the oral route was significantly more effective compared to the parenteral regimen [20]. In contrast with these data, however, Masood et al. reported that a single intramuscular dose of 600,000 IU of vitamin D3 was significantly more effective compared to an equal dose of orally administered dose and the levels of $25(\mathrm{OH}) \mathrm{D}$ levels remained higher at 6 months of follow up [21]. On the other hand, Wylon et al. reported that 8000 IU/day of oral vitamin D3 administered over 84 days was comparable to a single intramuscular dose of 100,000 IU in elevating 25(OH)D in vitamin D deficient adults [22]. Although conflicting results were reported on the efficacy of oral and intramuscular vitamin D3, our findings in postmenopausal women revealed that oral vitamin D3 was adequate to correct vitamin D deficiency.

When we reviewed the dose and frequency of administration of vitamin D3 which were used for supplementation, we found that the majority of included manuscripts reported using daily maintenance doses rather than a single high dose, or an initial high loading dose, followed by maintenance doses. Hackman and colleagues conducted a study on 59 vitamin deficient par- ticipants who were treated with either 50,000 IU/day for 10 days or 3000 IU daily for one month, followed by 1000 IU daily for another 2 months. The investigators concluded that both regimens were equally effective in correcting vitamin D deficiency [23]. Although small daily doses of vitamin D3 were used frequently for correcting vitamin $D$ deficiency, this review revealed variability in the efficacy of different tested doses. Indeed, in all included articles, doses beyond $2000 \mathrm{IU} /$ day were shown to be universally effective. On the other hand, while a dose of $1000 \mathrm{IU} /$ day was reported to be inadequate in some studies, doses which ranged from 200 to $800 \mathrm{IU} /$ day were universally ineffective as well. In line with this, ter Bor et al. conducted a study to examine the $25(\mathrm{OH}) \mathrm{D}$ response to $800 \mathrm{IU} /$ day of vitamin D3. The researchers concluded that this dose produced suboptimal results in $50 \%$ of participants after 10 weeks of treatment [24]. Based on this review, we recommended using a vitamin D3 dose beyond 2000 IU/day for postmenopausal women who suffer from vitamin $D$ deficiency. Our recommendations were in agreement with Chakhtoura et al., who conducted a systematic review and meta-analysis on vitamin D replacement in adults and older adults. They found that $2000 \mathrm{IU} /$ day was the minimum effective dose to raise $25(\mathrm{OH}) \mathrm{D}$ to $20 \mathrm{ng} / \mathrm{ml}$ [25]. These recommendations are also in line with the latest guidelines of the United States Endocrine Society, which recommended daily doses of 1500-2000 IU/day for adults aged more than 19 years to keep 25(OH)D within the reference range [26].

\section{Conclusions}

Oral supplementation with vitamin D3 is adequate to correct vitamin D deficiency in postmenopausal women. Although daily vitamin D3 doses below 1000 IU/ day were not consistently shown to be effective, doses of 2000-4800 IU/day were reported to be adequate in all reviewed studies to reach the target $25(\mathrm{OH}) \mathrm{D}$ of $30 \mathrm{ng} / \mathrm{ml}$.

\section{Disclosure}

The authors report no conflict of interest.

\section{References}

1. Lips $P$. Which circulating level of 25 -hydroxyvitamin $D$ is appropriate? J Steroid Biochem Mol Biol 2004; 89-90: 611-614.

2. Delvin E, Souberbielle JC, Viard JP, Salle B. Role of vitamin D in acquired immune and autoimmune diseases. Crit Rev Clin Lab Sci 2014; 51: 232247.

3. Cheng TY, Millen AE, Wactawski-Wende J, et al. Vitamin D intake determines vitamin d status of postmenopausal women, particularly those with limited sun exposure. J Nutr 2014; 144: 681-689.

4. Bilezikian JP. Primary hyperparathyroidism. J Clin Endocrinol Metab 2018, 103: 3993-4004. 
5. Bruyère $O$, Malaise $O$, Neuprez $A$, et al. Prevalence of vitamin D inadequacy in European postmenopausal women. Curr Med Res Opin 2007; 23: 1939-1944.

6. Tandon VR, Sharma S, Mahajan S, et al. Prevalence of vitamin d deficiency among Indian menopausal women and its correlation with diabetes: A first Indian cross sectional data. J Midlife Health 2014; 5: 121-125.

7. Li S, Ou Y, Zhang H, et al. Vitamin D status and its relationship with body composition, bone mineral density and fracture risk in urban central south Chinese postmenopausal women. Ann Nutr Metab 2014; 64: 13-19.

8. Chlebowski RT, Johnson KC, Lane D, et al. 25-hydroxyvitamin D concentration, vitamin $D$ intake and joint symptoms in postmenopausal women. Maturitas 2011; 68: 73-78.

9. Romagnoli E, Mascia ML, Cipriani C, et al. Short and long-term variations in serum calciotropic hormones after a single very large dose of ergocalciferol (vitamin D2) or cholecalciferol (vitamin D3) in the elderly. J Clin Endocrinol Metab 2008; 93: 3015-3020.

10. Apaydin M, Can AG, Kizilgul M, et al. The effects of single high-dose or daily low-dosage oral colecalciferol treatment on vitamin Dlevels and muscle strength in postmenopausal women. BMC Endocr Disord 2018; 18: 48.

11. Hansen KE, Johnson RE, Chambers KR, et al. Treatment of vitamin D insufficiency in postmenopausal women: a randomized clinical trial. JAMA Intern Med 2015; 175: 1612-1621.

12. Aloia JF, Dhaliwal R, Shieh A, et al. Vitamin D supplementation increases calcium absorption without a threshold effect. Am J Clin Nutr 2014; 99 : 624-631.

13. Talwar SA, Aloia JF, Pollack S, Yeh JK. Dose response to vitamin D supplementation among postmenopausal African American women. Am J Clin Nutr 2007; 86: 1657-1662.

14. Viljakainen HT, Palssa A, Kärkkäinen M, et al. How much vitamin D3 do the elderly need? J Am Coll Nutr 2006; 25: 429-435.

15. Cangussu LM, Nahas-Neto J, Orsatti CL, et al. Effect of vitamin D supplementation alone on muscle function in postmenopausal women: a randomized, double-blind, placebo-controlled clinical trial. Osteoporos Int 2015; 26: 2413-2421.

16. Golombick T, Diamond T. The effect of a combined oral calcium and vitamin $D$ supplement for treating mild to moderate vitamin $D$ deficiency in postmenopausal women. Clin Interv Aging 2008; 3: 183-186.

17. Thomas SD, Need AG, Nordin BE. Suppression of C-terminal telopeptide in hypovitaminosis $D$ requires calcium as well as vitamin D. Calcif Tissue Int 2010; 86: 367-374.

18. Mason C, De Dieu Tapsoba J, Duggan C, et al. Effects of vitamin D supplementation during weight loss on sex hormones in postmenopausal women. Menopause 2016; 23: 645-652.

19. Ceglia L, Niramitmahapanya S, da Silva Morais M, et al. A randomized study on the effect of vitamin D supplementation on skeletal muscle morphology and vitamin $\mathrm{D}$ receptor concentration in older women. J Clin Endocrinol Metab 2013; 98: E1927-1935.

20. Zabihiyeganeh M, Jahed A, Nojomi M. Treatment of hypovitaminosis D with pharmacologic doses of cholecalciferol, oral vs intramuscular; an open labeled RCT. Clin Endocrinol (Oxf) 2013; 78: 210-216.

21. Masood MQ, Khan A, Awan S, et al. Comparison of vitamin D replacement strategies with high-dose intramuscular or oral cholecalciferol: a prospective intervention study. Endocr Pract 2015; 21: 1125-1133.

22. Wylon K, Drozdenko G, Krannich A, et al. Pharmacokinetic evaluation of a single intramuscular high dose versus an oral long-term supplementation of cholecalciferol. PLoS One 2017; 12: e0169620.

23. Hackman KL, Gagnon C, Briscoe RK, et al. Efficacy and safety of oral continuous low-dose versus short-term high-dose vitamin D: a prospective randomised trial conducted in a clinical setting. Med J Aust 2010; 192: 686-689.

24. ter Bor EJ, van den Hoeven-van Kasteel W, Kelder JC, Lems WF. Prevalence and correction of severe hypovitaminosis $D$ in patients over 50 years with a low-energy fracture. Neth J Med 2015; 73: 124-128.

25. Chakhtoura M, Akl EA, El Ghandour $S$ et al. Impact of vitamin D replacement in adults and elderly in the Middle East and North Africa: a systematic review and meta-analysis of randomized controlled trials. Osteoporos Int 2017; 28: 35-46.

26. Pramyothin P, Holick MF. Vitamin D supplementation: guidelines and evidence for subclinical deficiency. Curr Opin Gastroenterol 2012; 28: 139-150. 